\title{
Green roofs pertaining to Storm Water Management in Urban Areas: Greening the City with Green Roofs
}

\author{
Tapaswini Mohapatra Samant
}

Architect \& Environmentalist, Architecture, Assistant Professor at Vaishnavi School of Architecture \& Planning,

\author{
Hyderabad, Telangana
}

\begin{abstract}
This report evaluated green roofs as a storm water management implement, particularly runoff from green roofs. Evapo-transpiration from planted green roofs and evaporation from unplanted media roofs were also compared. The kind of media type, media depth and long-term management of media were investigated. The objective of the report is to provide high-quality data which could be used to expand and refine expected runoff volumes and loadings from green roofs, as well as estimate factors which impact plant growth and development. Results specify that the green roofs are competent of removing $50 \%$ of the annual rainfall volume from a roof through retention and evapotranspiration. There are seasonal considerations as more runoff is generated during monsoon. Rainfall not retained by green roofs is held by Rain water harvesting technique. This report provides a complete review of the benefits of green roof, with an strong attention on its storm water management characteristic. This paper speaks the barriers to their more rapid transmission into Indian markets and makes recommendations on overcoming these barriers.
\end{abstract}

Keywords: Green roofs, storm water Runoff, Rain water harvesting, Rain gardens.

\section{INTRODUCTION}

Terrace gardening or green roofs is a smart and energysaving option to a conventional rooftop.Green roofs do not include container gardens on roofs where plants are grown in pots, but the terrace itself acts as a planting standard for growing the garden. Layer of soil and vegetation continuously covers the roof's surface. Green roofs are Multi-beneficial structural component that helps lessen the effects of urbanization on water quality.

This green roof technology includes the following:

- The roof structure and some insulation.

- A waterproofing covering, with root repulsive inserted in connecting or placed on top.

- A drainage layer, with water reservoirs.

- A landscape to hold the roots and the soil.

- A specialized growing medium which might not include soil.

- The plants

- A barrier between the plants and any roof to prevent root penetration.

TABLE I: TYPICAL GREEN ROOF LAYERS

\begin{tabular}{|c|c|}
\hline & Cross section of a green roof \\
\hline 1 & 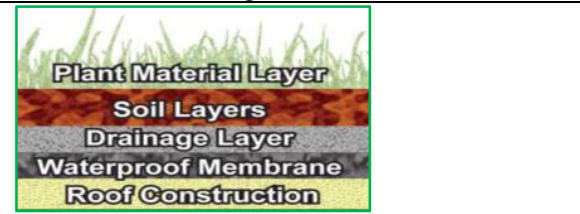 \\
\hline 2 & $\begin{array}{ll}\text { 1. } & \text { Sedum plants and growing material } \\
2 . & \text { Fleece mat } \\
\text { 3. } & \text { Drainage Layer } \\
\text { Root-resistant Membrane }\end{array}$ \\
\hline
\end{tabular}

Table I : cross sectional view of green roof indicating importance of each layer. (Multi layered structure)

\section{EARLY AND RECENT HISTORY}

Green roofs are not new inventions. They have been well thought-out in many countries for thousands of years. This is mainly because of the outstanding qualities of the collective plant and soil layer (sod). In cold climates they help hold heat in the building, and in warm climates they aid to keep the heat out. Green roofs can be dated to the hanging gardens of Babylon and were identified to exist in the Roman Empire, a rejoinder to population pressures in urban areas Fig. 1.

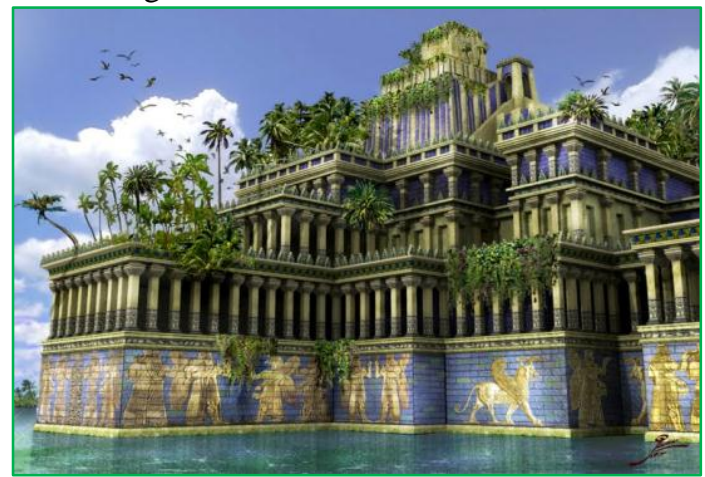

Fig. 1. Hanging gardens of Babylon

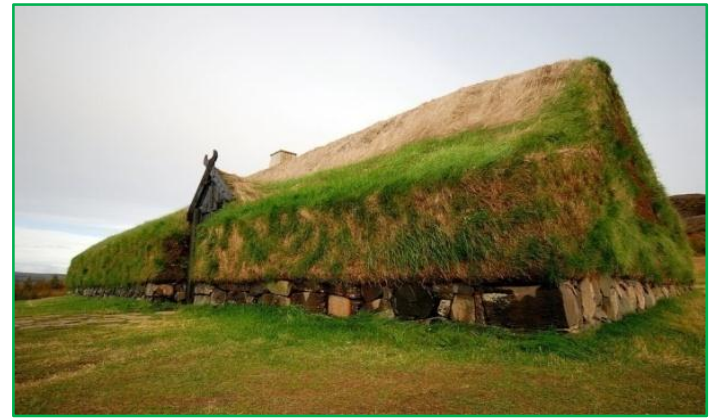

Fig 2: Viking houses 
The Romans also put trees on top of institutional buildings, such as the mausoleums of Augustus and Hadrian. The Vikings covered the walls and roofs of their homes with turf to guard against wind and rain Fig 2.

Canada claims quite a few Viking and French examples of sod roofs, exported to Newfoundland and Nova Scotia.

\section{A. Modern History :}

Developed in Germany in the 1960s, extend across Germany and Europe. It is fitting popular in cities for instance Chicago, Portland, and Atlanta .Amplified environmental awareness here in India has given rise to increased popularity of green roofs. Le Corbusier and Frank Lloyd Wright made broad use of green roofs in contemporary architecture.

Le Corbusier planned urban areas with roads placed on roofs in the middle of vegetation - his fifth point in " $A$ New Architecture "was roof gardens. He also included a green roof in the design of La Maison due Diable in 1913. F L Wright used rooftop and vertical gardens at Midway Gardens in Chicago, the Hollyhock House, the Cheney House, Falling Water, the Hillside Home School, and Horseshoe Inn, to name just a few of his projects.

\section{CATEGORIES OF GREEN ROOF}

There are two types of green roof systems - extensive and intensive. Extensive green roofs are identified by their little weight, less capital cost and low down maintenance. Intensive green roofs are characterized by their enlarged weight and high capital cost, rigorous planting and more maintenance requirements. Extensive and intensive green roofs are either reachable or unreachable.

For extensive roofs Fig. 3 the growing medium, usually made up of a mineral-based mix of sand, gravel, crushed brick, peat, organic matter and some soil, varies in depth between $5-15 \mathrm{~cm}$ - a weight increase of 72.6-169.4 kg per $\mathrm{m} 2$.

Due to the inconsequentiality of the soil and the extreme microclimate on many roofs, plants must be low and tough, typically native. Plants should be watered and fertilized only until they are reputable and after the first year, maintenance consists of few visits a year for weeding of insidious tree and shrub species, and safety and inspections.

For Intensive green roofs Fig. 4, the growing medium is soil-based, ranging in depth from $20-60 \mathrm{~cm}$, with a weight increase of 290-967.7 kg per m2.

Due to bigger soil depth the plant selection is more various with trees and shrubs, which allow a more intricate ecosystem to widen. Maintenance and watering are more challenging and ongoing than extensive green roof. Structural and landscaping consultations with an experienced installer are required.

Depending on substrate depth, about $105-155 \mathrm{~mm}$ thick substrate, has weight around $85-135 \mathrm{~kg}$ per square meter .Slopes over 10 degrees extra is required.

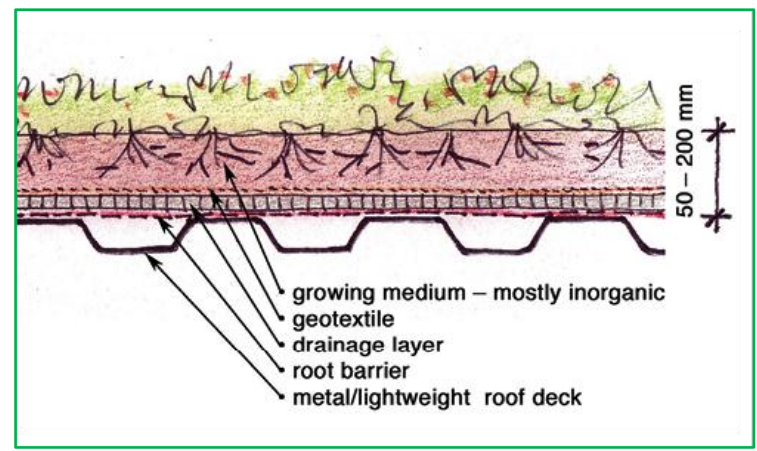

Fig. 3. Extensive green roof detail

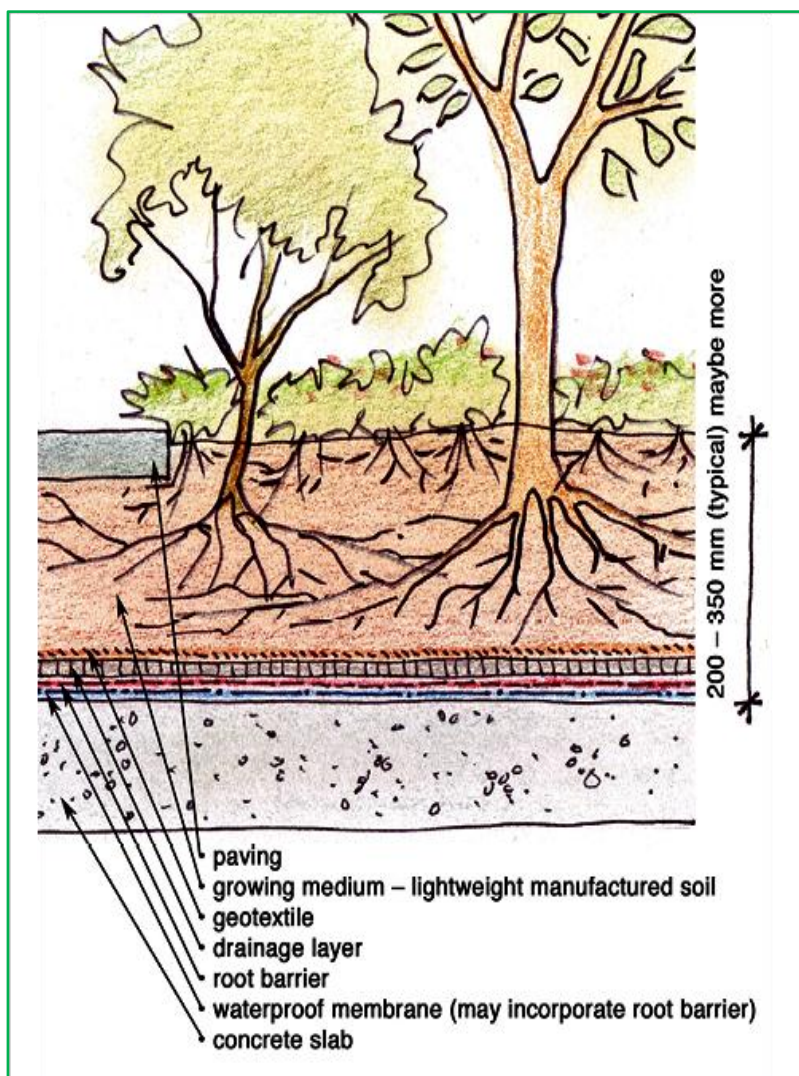

Fig. 4. Intensive green roof detail

TABLE II: COMPARISON OF EXTENSIVE AND INTENSIVE GREEN ROOF SYSTEMS

\begin{tabular}{|c|c|c|}
\hline & $\begin{array}{l}\text { Extensive Green } \\
\text { Roof }\end{array}$ & $\begin{array}{l}\text { Intensive Green } \\
\text { Roof }\end{array}$ \\
\hline $\begin{array}{l}\text { Brief } \\
\text { Description }\end{array}$ & $\begin{array}{l}\text { Thin soil, slight or no } \\
\text { irrigation, hectic } \\
\text { conditions for plants }\end{array}$ & $\begin{array}{l}\text { Profound soil, } \\
\text { irrigation system, } \\
\text { more encouraging } \\
\text { conditions for plants }\end{array}$ \\
\hline Advantages & $\begin{array}{l}\text { 1. Lightweight } \\
\text { 2. suitable for huge } \\
\text { areas } \\
\text { 3. suitable for roofs } \\
\text { with } 0-30^{\circ} \text { slope } \\
\text { 4. low maintenance } \\
\text { 5. frequently no need } \\
\text { for irrigation and } \\
\text { drainage systems } \\
\text { 6. comparatively } \\
\text { little technical } \\
\text { expertise needed }\end{array}$ & $\begin{array}{l}\text { 1. Greater variety of } \\
\text { plants and habitats } \\
\text { 2. Superior insulation } \\
\text { properties } \\
\text { 3. Can create a } \\
\text { wildlife garden } \\
\text { 4. on the ground } \\
\text { 5. Can be made very } \\
\text { gorgeous } \\
\text { 6. often visually } \\
\text { handy } \\
\text { 7. Varied utilization } \\
\text { of roof (i.e., for }\end{array}$ \\
\hline
\end{tabular}




\begin{tabular}{|c|c|c|}
\hline & $\begin{array}{l}\text { 7. regularly suitable } \\
\text { for retrofit projects } \\
\text { 8. can leave } \\
\text { vegetation to } \\
\text { develop } \\
\text { impulsively } \\
\text { 9. relatively } \\
\text { inexpensive } \\
\text { 10. looks more } \\
\text { natural } \\
\text { 11. easier for } \\
\text { planning authority } \\
\text { to demand green } \\
\text { roofs be a } \\
\text { 12. condition of } \\
\text { planning approvals }\end{array}$ & recreation, \\
\hline $\begin{array}{l}\text { Disadvanta } \\
\text { ges }\end{array}$ & $\begin{array}{l}\text { 1. more limited } \\
\text { choice of plants } \\
\text { 2. usually no access } \\
\text { for recreation } \\
\text { 3. or other uses } \\
\text { 4. unattractive to } \\
\text { some, especially in } \\
\text { winter }\end{array}$ & $\begin{array}{l}\text { 1. superior weight } \\
\text { loading on roof } \\
\text { 2. need for irrigation } \\
\text { and drainage } \\
\text { 3. systems hence } \\
\text { greater need } \\
\text { 4. for energy, water, } \\
\text { materials, etc. } \\
\text { 5. higher cost } \\
\text { 6. more intricate } \\
\text { systems and } \\
\text { 7. expertiserequired }\end{array}$ \\
\hline
\end{tabular}

Every green roof system can likely be a blend of intensive and extensive, depending on factors for example:

- Location

- Structural capacity of the building

- Material availability, financial plan et

- Client or tenant requirements

\section{QUANTIFIABLE AND QUALITATIVE BENEFITS}

Through the reintroduction of plants on the roofs of buildings, we can begin to rebuild some of the missing balance in the urban ecosystem. The greening of our urban region can also help us enhanced manage many of the waste we generate in the environment.

\section{A. Overview of benefits:}

- Reduce urban heat island effect

- Improve air quality

- Enhance bio diversity

- Extend useful life of roof

- Add beauty and usable space

- Enhance energy efficiency of buildings

Reduce storm water runoff

\section{STORM WATER MANAGEMENT}

The most important substantial benefit of green roofs is their potential to hold storm water. Engineering for urban development has conventionally focused on moving rainwater away from buildings and roads as rapid as possible.

Since much of the surface area in a city is moreover paved otherwise covered with buildings, rainwater which otherwise would have infiltrated into the ground or been intercept by vegetation, is abstracted from the cities through constructed storm water systems.

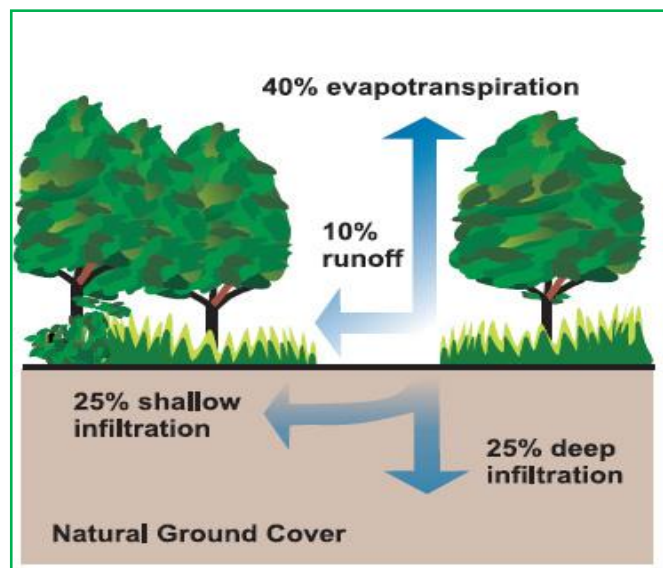

Fig. 5. With more ground covers more is the percolation Thereby increasing the ground water table

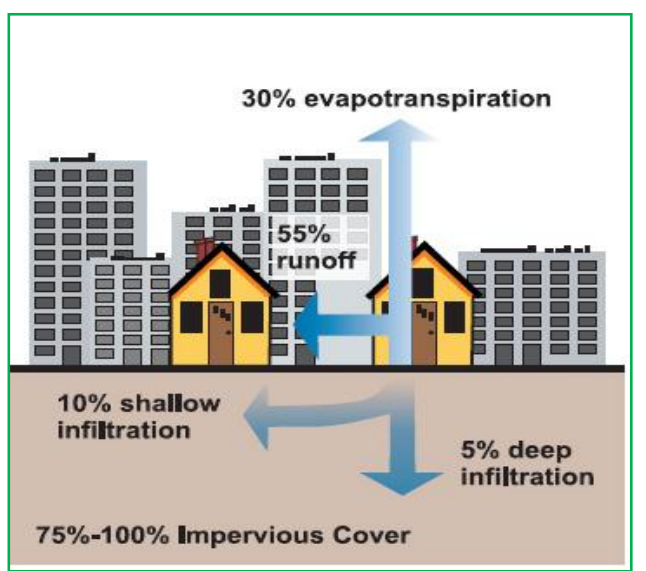

Fig. 6. With more impervious surface less percolation thereby decreasing the water table \& increasing water pollution is paving Over earth

For illustration, according to Urban Metropolitan Development Authority Studies, approximately 25\% of land areas, in new subdivisions in Indian metro cities are paved and non-porous. This non-porous landscape of urban areas and unmanaged storm water has created a number of problems such as, the infectivity of storm water. As it runs off impermeable surfaces, it picks up particulates, pesticides, oil, grease, heavy metals, rubber and garbage from roads, driveway, parking lots, lawns, roofs and pavement before it reaches storm drains. In a number of cities storm water is the number one cause of water pollution in local rivers.

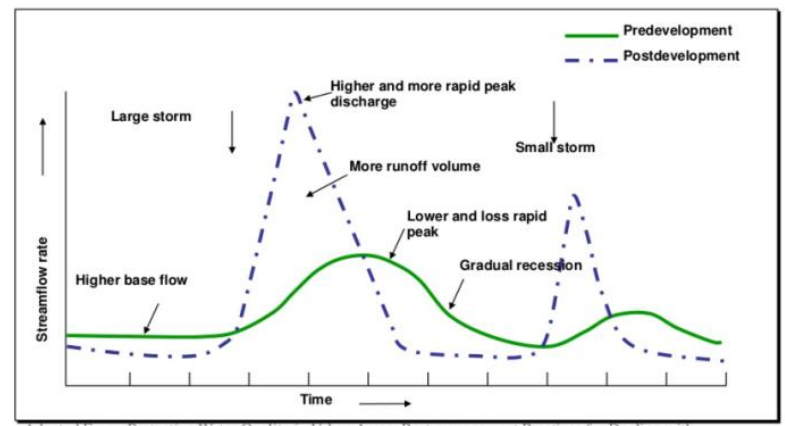

Fig 7 : Without development (pre-construction) - even flow \& uniform discharge without any stagnation .After development (post - -construction) - less discharge \& more fluctuating stagnations. 


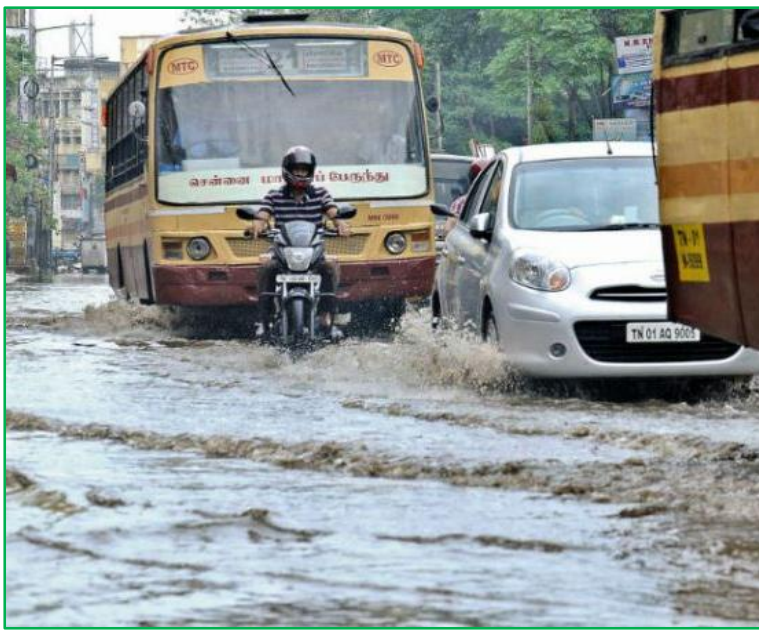

Fig. 8. Problems due to Storm water mismanagement on Indian roads.

\section{PROTECTION MEASURES FOR STORM WATER MANAGEMENT AT URBAN LEVEL}

As a protection and cost savings measure, many storm water systems run parallel to a city's sewage system, often spilling over into the sewage system if they cannot handle the volume of water during profound rainfall. This is usually a problem in grown-up urban areas. During a storm event, diluted raw sewage is discharged into the local streams and rivers, resulting in negative impacts.

Few additional problems area listed below:

Fall in local water tables and the bottom flow of streams and rivers, with up to $95 \%$ of natural precipitation being immediately discharged into major bodies of receiving water rather than infiltrating into the ground.

- Rigorous flooding, often ensuing in loss of human life due to the high volume of overflow.

- Erosion problems due to the turbidity of the storm water Storm Water Management Techniques using elements of landscaping, At Urban Levels (on broad base)

For solving some of these issues engage the expansion of storm water infrastructure, which can be a costly and troublesome process. Several cities, are commissioning consultants to study environmentally friendly, costeffective solutions that involve building percolative media or large, temporary storage facilities. Other natural alternatives comprise the use of swales adjacent to parking lots or any paved areas, constructed wetlands, rain arrels, cisterns, retention ponds and the use of porous pavement. These solutions still require some level of associated inspection and maintenance.

Therefore the management techniques are as the following:

Green Roofs

Recharge Garden Dry Well / Seepage Pit

Pervious Pavements

Vegetated Swale

Infiltration Trench

Infiltration basin -Infiltration planter

Wet Pond / Retention Basin

\section{GREEN ROOF - A MAJOR TECHNIQUE TO REDUCE STORM WATER RUNOFF}

A grass covered green roof with an 8-16. $(20-40 \mathrm{~cm})$ thick layer of substrate can hold up to $4-6 .(10-15 \mathrm{~cm})$ of water.

A three month long summer study showed that an extensive roof with a $7 \mathrm{~cm}$ deep vegetation layer produced no runoff, while the soil surface at grade, without planting, produced $42 \%$ runoff and a gravel surface produced $68 \%$ runoff.

Jaiswall a famous landscape architect in Mumbai , recently used his garage roof as a site for testing the stormwater reduction, claims of green roof systems. With a mixed layer of sedum and grass on only 2 " of soil he found that the roof retained between up to $90 \%$ of all the rain that fell on it, becoming less effective only during continuous and heavy rainfall.

Bottom line:

Increased runoff in urban environment is due to impervious surfaces

Gravel $=51 \%$ runoff while Vegetated $=18 \%$ runoff $10 \%$ cover in green roof yielded $3 \%$ decrease in runoff.

\section{A $2 \%$ slope with 4 inch media decreased runoff to} $13 \%$.

Most stormwater management represents a cost-based activity. If widely implemented, green roofs provide new opportunities to address urban stormwater management in a manner that also results in other proven environmental and social benefits.

\section{A. Green Roof Storm Water Runoff Management} Techniques

TABLE III: COMPARISON \& EXPLANATION ABOUT GREEN ROOF WATER MANAGEMENT \& QUANTIFYING THE RUNOFF WATER DATA

\begin{tabular}{|c|c|c|c|}
\hline \multicolumn{2}{|c|}{$\begin{array}{l}\text { By plant irrigation(Rain } \\
\text { gardens)-70\% }\end{array}$} & \multicolumn{2}{|c|}{$\begin{array}{l}\text { By rain water harvesting } \\
-30 \%\end{array}$} \\
\hline \multicolumn{2}{|c|}{$\begin{array}{l}\text { Storm water absorption } \\
\text { by plants }\end{array}$} & \multicolumn{2}{|c|}{$\begin{array}{l}\text { Collection of surplus } \\
\text { rain water }\end{array}$} \\
\hline \multicolumn{2}{|c|}{$\begin{array}{l}\text { Water loss by Evapo- } \\
\text { transpiration }\end{array}$} & \multicolumn{2}{|c|}{ Reuse after treatment } \\
\hline \multicolumn{2}{|c|}{ Can happen naturally } & \multicolumn{2}{|c|}{ Needs management } \\
\hline $\begin{array}{l}\text { 告 } \\
\stackrel{1}{c} \\
2 \\
\underline{\tilde{y}} \\
\underline{\tilde{y}}\end{array}$ & 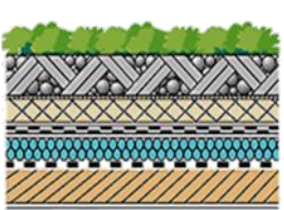 & 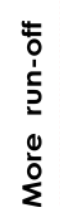 & 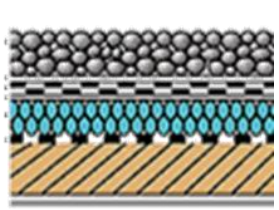 \\
\hline & & & \\
\hline
\end{tabular}




\section{RAIN GARDENS}

A rain-garden is plotted landscaping that allow rainwater runoff from impervious urban areas, like roofs, driveways, walkways, parking lots, to get captivated. This reduces rain runoff by allowing storm water to permeate into the ground. They should be designed for specific soils and climates. The purpose of a rain garden is to improve water quality in nearby bodies of stream. Rain gardens can reduce on the amount of pollution reaching creeks and streams by up to $30 \%$.

Native and adapted plants are recommended for rain gardens because they are more tolerant of one's local climate, soil, and water conditions; have deep and variable root systems for enhanced water infiltration and drought tolerance; habitat value and diversity for local ecological communities; and overall sustainability once established.

The plants - a selection of wetland edge vegetation, such as wildflowers, sedges, rushes, ferns, shrubs and small trees - take up excess water flowing into the rain garden.. The whole roof garden can become a rain garden, and each component of the whole can become a smallscale rain garden in itself.

Rain garden helps in utilizing the biological, physical, and chemical processes found in the plants and soil to naturally remove pollutants from the rainwater so they do not enter the storm drainage system.

\section{A. Benefits of rain gardens:}

Bioremediation and phytoremediation

Reduces runoff volume and discharge rate of water into the storm drainage system

Enhance Aesthetics

Provide Habitat Benefits

Rain Gardens may Require Watering in dry season

\section{B. Water Filtration and Quality Improvement}

Greened surfaces not only retain much of the precipitation that falls on them, they also moderate the temperature of the water and act as natural filters for any of the water that happens to runoff. Heavy metals and nutrients carried by the rain end up being bound in the substrate instead of being discharged.

Studies show that as much as $\mathbf{9 5 \%}$ of cadmium, copper and lead, and $16 \%$ of zinc have been taken out of rainwater by green roof systems.

\section{Methods of storm water purification (natural):}

Phytoremediation describes the treatment of environmental problems (bioremediation) through the use of plants that lessen the environmental difficulty without the need to dig the contaminant material and dispose of it elsewhere.

Phytoremediation consists of mitigating pollutant concentrations in contaminated soils, water, or air, with plants able to contain, degrade, or eliminate metals, pesticides, solvents, explosives, crude oil and its derivatives, and various other contaminants from the media that contain them.

\section{PLANTS \& SOIL TYPE FOR GREEN ROOF}

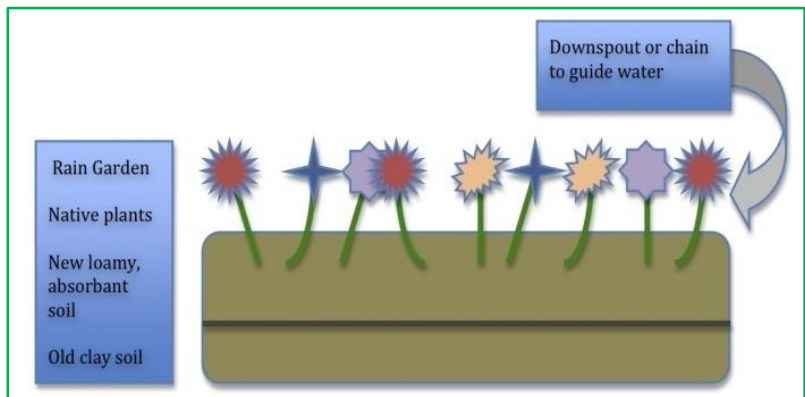

Fig. 9. Problems due to Storm water mismanagement on Indian roads.

TABLE IV: DEPICTION OF VARIOUS DEPTH \& WEIGHT OF TYPICAL GREEN ROOF

\begin{tabular}{|l|l|l|}
\hline Material & Depth & Saturated Weight \\
\hline Vegetation layer & $25 \mathrm{~mm}$ & $\begin{array}{l}25 \mathrm{~kg} / \mathrm{m} 2 \text { fully } \\
\text { saturated }\end{array}$ \\
\hline $\begin{array}{l}\text { Extensive green roof } \\
\text { substrate }\end{array}$ & $75 \mathrm{~mm}$ & $\begin{array}{l}75 \mathrm{~kg} / \mathrm{m} 2 \text { fully } \\
\text { saturated }\end{array}$ \\
\hline $\begin{array}{l}\text { Roofdrain drainage } \\
\text { layer }\end{array}$ & $30 \mathrm{~mm}$ & $\begin{array}{l}10 \mathrm{~kg} / \mathrm{m} 2 \text { fully } \\
\text { saturated }\end{array}$ \\
\hline TOTAL & $130 \mathrm{~mm}$ deep & $110 \mathrm{~kg} / \mathrm{m} 2$ loading \\
\hline
\end{tabular}

\section{A. Plants Suitable For Extensive type Of Growing Medium}

Sedum (stone-crop) and delosperma (ice plant) are common varieties.. As a result, a green roof with mostly sedum species can usually survive 2 to 3 weeks without irrigation.

\section{B. Plants Suitable for Intensive type of Growing Medium}

With deeper soil, a wider range of plantings become possible. Several species of grasses, alliums, herbs and wildflowers can thrive in $10 \mathrm{~cm}$ of growing medium.

\section{RAIN WATER HARVESTING}

One of the questions that frequently arise when discussing green roofs with clients is the feasibility of collecting the runoff from the roof for various uses in and around a building. Often this interest is focused on reducing the watering requirement for the roof - after all, in drought prone areas, watering your roof seems to be wasteful, right. If your desire is simply an ecologically friendly roof, why not just install a green or white roof.

It would seem that most harvested rainwater can easily be made safe to drink if the levels of heavy metals are not too high. In many cases, runoff from a green roof enters the filtering/disinfecting process cleaner than water harvested from many popular roofing alternatives - especially with respect to heavy metals.

One should keep in mind that the volume of rainwater collected from a green roof will be less than the volume collected from a less absorbent roofing material. Many studies suggest that around $60 \%-80 \%$ of the raindrops that 
fall on a green roof will never make it into a collection tank, thus reducing the roof's effectiveness at producing storable water. This fact can be both positive and negative, depending on project priorities.

Because less water is captured per square-foot from a green roof vs. a metal or shingle roof, green roofs can use smaller, cheaper water storage systems. In addition, if stormwater management is a primary project goal, combining rainwater collection with living roofs can be a great tactic.

Doing so will effectively increase the roof's capture efficiency to nearly $100 \%$ while providing a sustainable source of irrigation water for the roof during the summer months. It is worth noting that deciding against a green roof may be the right call if a project or client needs larger quantities of captured water; it is especially important that consultants be well versed in both technologies to help a client make the right decision.

\section{COST BENEFIT ANALYSIS}

\section{- Costs per square foot (LEED STANDARDS} 2005,UNIVERSAL )

- Intensive green roofs should cost between $\$ 16$ and $\$ 35$ per square foot

- Extensive green roofs should cost between $\$ 7$ and $\$ 35$ per square foot

- Installations of green roofs are sometimes eligible for tax relief, energy conservation credits or lower storm water charges from municipalities and should be investigated.

\section{A. Indian standards:}

Initial costs: $120 \%$ greater than conventional (including upgrade of steel structure)

-Soil and plant costs

-SAVINGS: • Annual energy savings (Rs.8/sf)

-Annual operations costs: replacement costs (1 time), amortized over 99 years.

-Deduct for reduced maintenance costs of HVAC system Post-construction (actual costs):

Simple Payback: 5 years

\section{PROS \& CONS}

\section{A. Advantages of green roofs}

There are many advantages in having a green roof. The first advantage of a green roof is lessening on the amount of storm water runoff this is because instead of water just going from the roof of a concrete building onto the ground, a green roof's plants will absorb some of the water. Another big advantage of having a green roof is the reduced urban heat island effect from having too much pavement and not enough wildlife in urban areas. Green roofs increase the life of roof membranes by limiting the amount of damaging UV exposure. Also, green roof's provide ecosystem services in urban areas and increase the amount of urban wildlife. A further advantage of a green roof is the better regulation of building temperatures compared to non-green roof buildings. Green roofs have been shown to increase fire resistance and to improve air quality also.

Base line benefits:

Irrigation of Landscaped areas \& Gardens

Firefighting Storage

Reduced Peak Volume of Storm water

Reuse for Grey Water .i.e. flushing toilets

\section{B. Disadvantages of Green Roofs}

Despite all of the advantages of green roofs, there are some disadvantages. One disadvantage is that green roofs initially have a higher cost to build than traditional roofs. They are also costly with repairs. Green roofs also require stronger roof beams to support the layers of the green roof, mostly the soil. One more disadvantage of a green roof is that when they are built in places susceptible to bad weather, such as seismic zones or windy places there is a great chance of the plants not surviving. In conclusion, although green roofs greatly help our environment, they have some costly disadvantages

\section{Base line limitations}

Limited Suitability

Requires Proper Maintenance

Pumping Cost may involve if sub surface storage is provided

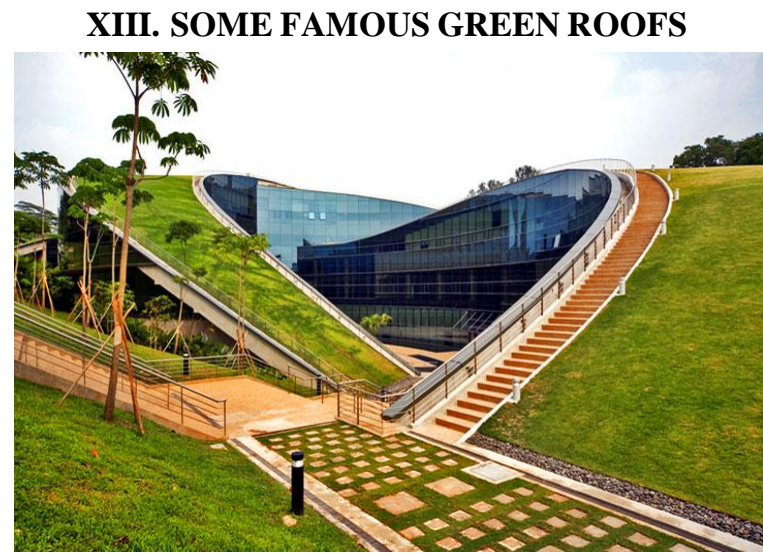

Fig. 10. Nanyang Technical University in Singapore

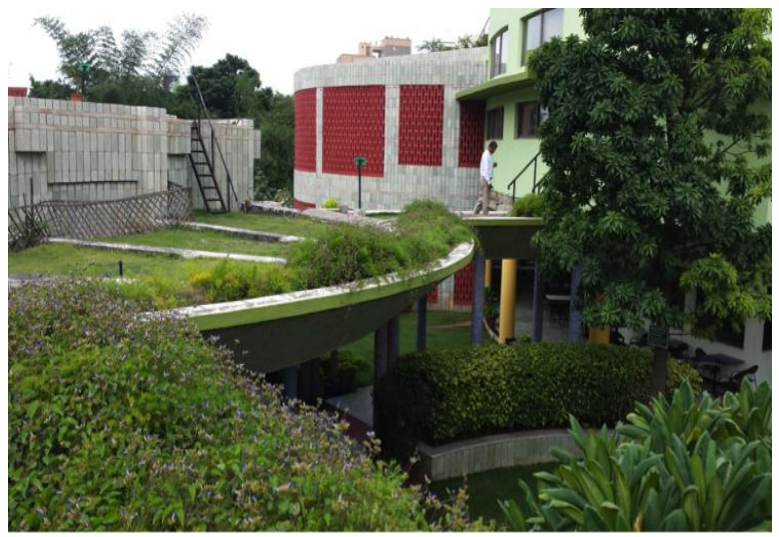

Fig. 11. CII Building Hyderabad

\section{CONCLUSION}

Most green roofs should be able to use the existing rooftop drainage system with only minor modifications.Due to 
benefits including energy savings, enhanced roof life, stormwater reduction, beautification, and air quality improvement, green roofs make sense for all new roofs. By 2020, India requires all new roofs to be either reflective-coated or green roofs.

Green roofs were most effective at delaying and reducing peak flows when they were not fully saturated. Rapid peak flows, i.e. high-intensity, short duration rainfalls were attenuated more than lower intensity, high-total volume longer period flows.

The report has illustrated how roof drainage systems are a key, but often overlooked, element of urban drainage infrastructure. It has also been shown that their design is a complex process, which relies heavily on gutter outlet performance.

Although green roofs are an attractive alternative, it is probable that conventional roof surfaces will continue to dominate non-urban sector. However, it is likely that green roofs will experience a step-change in acceptance by the urban sector once more becomes more aware for its known about its performance and sustainability.

\section{ACKNOWLEDGMENT}

I thank generously all the STAFFS of Vaishnavi School of architecture \& planning, for their kind help and cooperation throughout my study period. Special thanks to Professor. KJAB Babu, Professor N. Rama Swamy, \& Professor G. Neelima (Guide).

It is my privilege to thank my parents $\mathrm{Mr}$. R.K. Mohapatra, Mrs .Kalpana Mishra \& My Husband Mr. Rajat Kumar Samant for their constant encouragement \& support throughout my study period.

I am extremely thankful to my college Mr. Kirthi Chandra working at Vaishnavi School of architecture \& planning, for providing me necessary technical suggestions during my article pursuit.

Subject area experts from different environment protection organizations around Hyderabad.

\section{REFERENCES}

[1] Bass, B. and B. Baskaran. 2003. Evaluating Rooftop and Vertical Gardens as an Adaptation Strategy for Urban Areas. National Research Council Canada, Report No. NRCC-46737, Toronto, Canada.

[2] Banting, D., H. Doshi, J. Li, and P. Missios. 2005. Report on the Environmental Benefits and Costs of Green Roof Technology for the City of Toronto. Department of Architectural Science, Ryerson University.

[3] Hutchinson, D., P. Abrams et al. 2003. Stormwater Monitoring Two Ecoroofs in Portland, Oregon, USA. Proceedings of Greening Rooftops for Sustainable Communities, 2003, Chicago, IL.

[4] Scholz-Barth, K. 2001. Green Roofs: Stormwater Management from the Top Down. Environmental Design \& Construction.

[5] Peck, S. and M. Kuhn. 2001. Design Guidelines for Green Roofs. National Research Council Canada, Toronto, Canada.

[6] Scholz-Barth, K. 2001. Green Roofs: Stormwater Management from the Top Down. Environmental Design \& Construction.

[7] Personal correspondence with Tom Liptan, Portland Bureau of Environmental Services, 18 December 2007.

[8] Clark, C., P. Adriaens, and F.B. Talbot. 2007. Green Roof Valuation: A Probabilistic Analysis of Environmental Benefits.
[9] Liu, K. 2002. A National Research Council Canada Study Evaluates Green Roof Systems' Thermal Performances. Professional Roofing.

[10] Bass, B. and B. Baskaran. 2003. Evaluating Rooftop and Vertical Gardens as an Adaptation Strategy for Urban Areas. National Research Council Canada, Report No. NRCC-46737, Toronto, Canada.

[11] http://en.wikipedia.org/wiki/Green_roof

[12] http://www.lid-stormwater.net/greenroofs/greenroofs_home.htm

[13] http://www.epa.gov/heatisland/strategies/greenroofs.html

[14] http://en.wikipedia.org/wiki/Phytoremediation

[15] http://en.wikipedia.org/wiki/Bioremediation

[16] http://www.hrt.msu.edu/faculty/Rowe/Green_roof.htm

[17] http://www.greenroofs.net/index.php?option=com_content\&task=vi ew\&id=26\&Itemid $=40$

[18] http://www.nrel.gov/docs/fy04osti/36060.pdf

[19] http://www.garlandco.com/green-roof-history.html

\section{BIOGRAPHY}

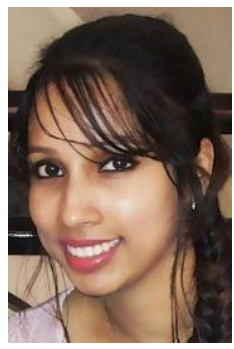

Tapaswini Mohapatra Samant, Architect \& Environmentalist Presently working as Assistant Professor in the department of Architecture at Vaishnavi School of Architecture \& Planning (VSAP), Hyderabad. 